\title{
An Analytical Study on Executive Compensation with a Particular Focus on Selected Indian Companies
}

\author{
Helena M. N Ngalandji- Hakweenda \\ MBA, Tutor-Marker for the subjects Introduction to Human Resources and Self Development, at the Namibia College of Open \\ Learning, Windhoek, Namibia. Postal address: P.O.Box 86962, Eros, Windhoek, Namibia \\ Email: hngalandji@gmail.com
}

\section{Doi:10.5901/mjss.2014.v5n23p591}

\begin{abstract}
Executives (managers) in any organisation are the live wires. They cannot be treated as yet another employee. They play a vital role in all management functions such as planning, organisation, directing, coordinating and controlling. India is one of the third world countries with a rapid growing economy, and in particular India is endorsed to be rich in human capital. To mention a few, the world best doctors and engineers are known to be made from India. However, recent researchers on compensation have revealed that most Indian best talents they are not happy with their compensation package. Given such conditions, it became imperative to conduct an analytical study on Executive compensation with a particular focus on selected companies in India. The primary objective of this study therefore was to find out the means of compensating executives which are currently implemented within the 5 selected Indian companies; understand how executive remuneration affects their performance; identify and study the arising gaps in executive compensation; understand why Indian executives are leaving to other countries; and to look into preventative measures to limit the exodus to other companies. The study was undertaken as a freelance research for the period of six weeks at the following selected companies; Tata Bp Solar limited Company, Wipro, Infosys and HDFC Indian bank.
\end{abstract}

Keywords: Executive Compensation, Minimum wages, Incentives, Stock Option, Perquisites (Perk), Compensation Committee, Golden Parachute

\section{Introduction}

In modern business, company executives hold the most pivotal roles in an organization. All over the world, modern corporations are constantly trying to come up with a compensation plan to attract, hold, and motivate executives. The compensation plans are numerous and every company attempts to innovate a compensation plan that is better than the other. Most executive compensation plans emphasize current and deferred salary provisions or a combination of both.

The first step in the establishment of executive compensation is to provide an adequate job evaluation and rating plan. Payment for results philosophy must be adopted. What an executive has done and what is likely to do in the future must be critically appraised

Although there is substantial heterogeneity in pay practices across firms and industries, executive pay packages contain four basic components: a base salary, an annual bonus to accounting performance, stock options, and long-term incentive plans (including restricted stock plans and multi-year accounting-based performance plans). In addition, executives participate in "broad-based" employee benefit plans and also receive special benefits, including life insurance, car schemes, housing allowances and supplemental executive retirement plans.

This paper attempts an analytical study on executive compensation with a particular focus on selected companies in India. For the purpose of analysis, the research findings were presented in a statistical form. Descriptive statistics like frequency and percentage were used to analyse the data collected. The original research paper of the study reviewed and under discussion is divided into three sections. Section one is the introduction and reviews of related literature while section two analyses the data and interpretations. Section three contains findings, conclusion and recommendations.

\subsection{Executive Compensation in India}

Although there is substantial heterogeneity in pay practices across firms and industries, executive pay packages contain four basic components: a base salary, an annual bonus to accounting performance, stock options, and long-term incentive plans (including restricted stock plans and multi-year accounting-based performance plans). In addition, 
executives participate in "broad-based" employee benefit plans and also receive special benefits, including life insurance, car schemes housing allowances and supplemental executive retirement plans (SERPs).

Over the years, a number of studies looking into the executive remuneration trends in India have been carried with the following findings:

The most comprehensive international comparison to date in the academic literature is Abowd and Bognanno (1995), who use data from four international consulting firms to analyze 1984-1992 pay in twelve OECD countries (Belgium, Canada, France, Germany, Italy, Japan, the Netherlands, Spain, Sweden, Switzerland, the UK, and the US). They adjust for tax rates (on both direct pay and perquisites), purchasing power, and public benefits, and find that pay for US CEOs exceeds pay in other countries even after adjusting for these differences. Interestingly, they find that the "US premium " is limited to the CEO: there is no significant difference between US vs. international pay practices for lowerlevel executives and production workers. Although our understanding of international differences in executive compensation practices is far from complete, several results emerge from the existing research.

First, the elasticity of cash compensation to company size is remarkably constant across countries: Zhou (1999), for example, reports pay-size elasticity's for the US, Japan, the UK, and Canada of .282, .247, .261, and .247, respectively. Second, the elasticity of cash compensation to stock- price performance, and the relation between CEO turnover and performance is roughly comparable in the US, Japan, and Germany (Kang and Shivdasani, 1995; Kaplan, 1994a, 1994b, 1997).

Third, stock-based incentives from stock options and stock ownership are much higher in the US than in other countries (Abowd and Bognanno, 1995; Kaplan, 1997). A final, but more speculative, result emerging from the existing data is that pay levels and structures are converging, reflecting an increasingly global market for managerial talent. Canadian and Mexican companies, for example, routinely now include US companies in peer groups used to determine competitive pay levels. US companies routinely export pay practices (including stock option grants) to executives of foreign subsidiaries, putting pressure on the pay policies of local competitors. And, foreign companies acquiring US subsidiaries face huge internal pay inequities, often resolved by increasing home-country executive pay. In addition, legal prohibitions on granting executive stock options in Japan were lifted in April 1997,

The number of high net worth individuals (HNWIS) in India is growing at a faster pace than anywhere in the world. According to the 2004 world Wealth report, published by Capgemine and merill Lynch,the increase in India was 22 percent, against 12 percnt in the US.(HNWIS)are defined as people with financial assets of at least $\$ 1$ million,excluding real estate.)There were roughly 61,000 HNWSIS in India at the end of 2003(aswathappa, 2005: 331)

Many of the big earners are in companies, partnerships, brokerages and private firms that don't need to declare their numbers. Finding out details about them is very difficult.

Indians unlike Americans do not wear their pay cheques on their sleeves. It is not in their culture to do so. Besides, Indians always have to worry about harassment by the taxmen, a particularly rapacious breed that winks at evaders while hounding the honest citizens. The place where one can really find highly paid executive is the finance sector. Perched right on top are heads of foreign banks.US banks are known to be the most liberal paymasters. Citigroup India CEO Sanjay Nayar gets a package between Rs 4 crore and Rs 4.5 crore. Head of the consumer bank division sarvesh swaroop is close on his heels with Rs 3 crore.

Vishwarvir Ahuja, managing director and CEO of Bank of America, Earns Rs 2.5-3 crore. This is primarily because a major consideration while fixing compensation for a foreign bank head is how important the region is for the bank global business. In the case of Bank of America, its Indian operations are minor part. Standard Chartered Grindlays, on the other hand, is an Asian Bank with a vast Indian presence. It pays its CEO's Chris Low Rs 4-4.5 crore. Niall Booker of HSBC is in the same league. European banks are more conservative. The Dutch banks are the most frugal of the lot. Gunit Chadha of Deutsche Bank makes Rs 2 crore(up from Rs 52.8 lakh without perks and benefits at IDBI Bank)and Romesh Sobti, executive V-Pand country representative of ABN Amro receives Rs 2-2.5.

Indian banks such as HDFC and ICICI pay much less. Aditya Puri of HDFC Bank gets Rs 69 lakh and K.V Kamath of $\mathrm{ICICl}$ receives Rs 1.15 crore.The really down -markets are the public sector banks. State Bank of India chairman A.K Purwar earned Rs 5 lakh in 2003-04. PSU banks give perks that are rarely quantified at real value

\subsection{Extent of Pay}

Theoretically, remuneration of managerial personnel is supposed to be guided by job descriptions, job evaluations, salary grades with ranges of pay in each grade, and salary surveys. But in practice the norm seems to have been thrown to winds and exorbitant amounts are paid to decision makers in organizations. (Aswathappa 2003:336).

Table 1 below gives details about the remuneration paid to chief executives in India. At the top BML Munjal who 
grossed Rs 11.7 crore during 2003-04, followed by the two Ambanis cleared Rs 11.62 crore each. Wipro Chairman Azim Premjii recently took Rs 566 crore home. This is not his remuneration in the strict sense, which however stood at Rs 1.8 crore. The huge sum he received was the dividend he got on his 83.74 per cent holding in the group of companies.

Table 1. Executive Remuneration

\begin{tabular}{|c|c|c|c|}
\hline $\begin{array}{l}\text { (2003-04)Amount } \\
\text { (Rs Crore) }\end{array}$ & Name & Designation & Company \\
\hline 11.71 & BML Munjal & Chairman & Hero Honda Motor \\
\hline 11.62 & Mukesh Ambani & Chairman \&managing Director & Reliance Industry \\
\hline 11.62 & Anil Ambani & Vice-Chairman\&managingDirector & Reliance Industry \\
\hline 11.53 & Pawan Munjal & Managing Director & Hero Honda Motor \\
\hline 11.36 & Akio Kazusa & Joint Managing Director & Hero Honda Motor \\
\hline 10.12 & Shinichi Nakayama & Wholetime Director & Hero Honda Motor \\
\hline 8.40 & Pankaj R Patel & Managing Director & Cadila Healthcare \\
\hline 5.70 & Vivek Paul & Vice chairman & Wipro \\
\hline 5.12 & Onkar S Kanwar & Chairman \&managing Director & Apollo Tyres \\
\hline 4.20 & Kammal K.Singh & Chairman \&managing Director & Rolta India \\
\hline 4.05 & D S Brar & CEO \& Managing Director & Ranbaxy Labs \\
\hline 3.79 & Ajit Gulabchad & Chairman \&managing Director & Hindustan Construction \\
\hline 3.65 & Brian W Tempest & Managing Director\& CEO & Ranbaxy Labs \\
\hline 3.65 & Suresh Krishna & Chairman \&managing Director & Sundramm Fasteners \\
\hline 3.33 & Dr K Anji Reddy & Executive chairman & Dr. Reddys Labs \\
\hline 2.98 & S C Mehta & Managing Director & Deepak Fertilizers \\
\hline 2.95 & N S SeKhasaria & Managing Director & Gujarat Ambuja \\
\hline 2.88 & V K Kaul & Additional Director & Ranbaxy Labs \\
\hline 2.76 & Sudhir Mehta & Executive Chairman & Torrent Pharma \\
\hline 2.62 & B N Kalyani & Chairman \& managing Director & Bharat Forge \\
\hline 2.47 & M.S Banga & Chairman & Hindustan Lever \\
\hline
\end{tabular}

Note: Remuneration (in 2003- 04) principally includes commission, salary, other perquisites and sitting fees. It does not include value of stock options granted.

Source: Business Line, August 10, 2004.

\subsection{Factors affecting pay differences}

A history of executive compensation shows that a combination of events has created today's situation in the United States. Strong demand, the tax structure, stock market performance, and pay-for-performance notions have all contributed. Many organizations, especially large ones, administer executive compensation differently from compensation for lower-level employees (Maths and Jackson (2003;p 427)

In order to determine the extent of pay differences in similar jobs, one needs to hold constant the effects of factors such as the following :( Hartman 2003: 46)

a. Type of industry and company: Studies suggest that employees in some jobs can receive as much as a 20 percent simply by switching industries in the same geographic area while performing basically similar jobs. Also firms and industries that have a greater ability to pay their employees should not be compared with those that are less profitable.

b. Size of organization: Research indicates that small companies usually pay less than large organizations. Other suggests that women "like" smaller companies. Pay differences between genders may result, but are women less satisfied.

c. Marital status: Macro data shows that the economic effects of marriage and parenthood are significant and often directly opposite in their effects on men and women. For instance, marriage increases a man's participation rate in the labor force compared to single men and reduces a woman labor force participation compared to single women. Also married man's hours worked annually increase with the number of children, while a married woman's tend to decrease with more children. Thus married men with children work more and earn more than single men, while the reverse is true for women.Infact women who remain single earn over 93 
percent of the income of single men. In the end, the major differences are not between men and women but between married women and everyone else.

\subsection{Determining "Reasonableness" of Executive Compensation}

The reasonable of executive compensation is often justified by comparison to compensation market surveys, but these surveys usually provide a range of compensation data that requires interpretation. Various questions have been suggested for determining in executive pay is "reasonable" in a specific instance, including the following: (Source: Wikipedia of Executive compensation).

Would another hire this person as an executive?

How does the executive's compensation compare with that for executives in similar companies in the industry?

Is the executive's pay consistent with pay for other employees in the company?

What would an investor pay for the level or performance of the executive?

Undoubtedly, the criticisms of executive compensation will continue as huge payouts occur, particularly if organizational performance has been weak. Hopefully, boards of directors of more corporations will address the need to better link organizational performance with variable pay rewards for executives and other employees.

\section{Summary of Findings}

\subsection{Objective 1: Find out the means of Executive Compensation package which are currently implemented within companies in India.}

At the heart of most executive compensation plan of sampled companies in India is the idea that executives should be rewarded if the company grows in profitability and value over a period of years. As the case with executive of any country in the world that the executives falling high tax brackets, most executives want their compensation packages offered in ways that offer significant tax savings. Thus total compensation packages are most significant than their base pay.

Except the commission, companies in India offer the five common executives compensation components which are salaries, annual bonuses, long-term incentives, supplemental benefits and perquisites.

With all the difficulties known in determining the executive performance, most companies in India emphasize performance as the major factor considered when determining the payment level for their executives. Moreover companies in India give strong recognition to the fact that bonus compensation must reflect some performance measure if it is to be meaningful.

What is more logic with sampled companies in India is that most companies feel that their executive compensation package is at par with others. The result being that the companies identify the industry of the company as the key factor for compensation benchmarking purposes.

\subsection{Objective 2-:Understand how executive remuneration effects their performance.}

Most sampled companies in India strongly support the fact that executive compensation levels are linked to organisational performance. As it is the practice in many settings, Companies in India use the financial measures such as return on equity, return to shareholders, earnings per share, net income before taxes. However, today a number of companies in India also incorporated non-financial organisational measures of performance when determining executive bonuses and incentives. Customer satisfaction, employee satisfaction, market share, productivity and quality are other areas measured for executive performance rewards. The emphasize given by the companies on non financial measure is that it curb the known manipulation in financial performances that may impact the company long term growth such as executive manipulating earnings per share by selling assets, liquidating inventories.

Therefore because of the executives significant ability to influence organization or company performance, top managers and executives are strategically important group whose compensation warrants spread attention.

\subsection{Objective 3: Identify and study the arising gaps in executive compensation}

Most companies in India have established a system which they follow when determining reasonable compensation for their executives. The three categories of the structure are; individual perspective and the company perspective and Industry. With the structure existence, the study identified the major complains raised by the executives to constitute unfair practices in regards to promotions and lack of recognition to executives good contribution. This simplifies that that 
there are gaps that need to be addressed to effect proper and regular movement of the existing set system.

Furthermore, reasonableness of executive compensation in India is most justified by comparison to compensation market surveys, but these surveys usually provide a range of compensation data that requires interpretation.

In addition, the compensation committee established in most companies in India composed only of officers of the company this include the company Human Resource General Directors, Deputies General managers and senior executives.

The compensation programme established in most sampled companies in India have not spell out the performance theme the stated peak factor considered in rewarding their executives. It is stated that most companies has established the compensation programme only with the objective to encourage executives to manage from the perspective of owners instead of objective to differentiate payments between best performers and poor performers.

The ethical conduct of most companies are not well established in helping ensuring that stock based grants reward only those executives who benefit the company. However most companies stated that the Employee Stock Option Plan (ESOP) programme is given at an interval of two year

\subsection{Objective 4-: Understand why Indian Executives are leaving to other countries.}

The complains and concerns prevailing in few companies by executives in regard to compensations include unfair payment practices among executives of companies in one industry, promotions not rightly given ,higher responsibilities given but not recognized for their contributions, inadequate payment and career growth. As a result of this there are a meager number of executives in sampled companies in India leaving the country for greener pastures.

\section{Conclusions}

In modern business the executive hold the most pivotal place in an organization and the modern corporations are constantly trying to come up with a compensation plan to attract, hold and motivate the executives. The compensation plans are numerous and every company attempts to innovate a compensation plan that is better than the other. Compensation in the Indian standard has been competitive and appropriate as a developing nation. However, with the opening up of Indian economy and stiff competitors globally has resulted to Indian best talents resigning and leaving the country for greener pastures. conducted.

Hence, an analytical study on executive compensation with a particular focus on selected companies in India was

The following conclusions have been drawn from the study:

1. Almost all the companies in India have implemented the performance factor in determining their executive appropriate payment.

2. Two-fifth of the companies in India has considered the industry as the key factor in comparison for compensation benchmarking purposes.

3. The fourth -fifth of the companies feels that executive compensation is at par with other competitors

4. Most of the companies are fully satisfied with the existing executive compensation package.

5. Indeed seventy six percent of the companies are fully satisfied with their base pay.

6. Most companies are also satisfied with the executive bonus and long term incentives.

7. Eighty per cent of the companies are satisfied with perquisites.

8. Hundred percent of the companies have fully supported and agreed to the statement that executive remuneration affects performance. Hence a good CEO or any executive can have a positive effect on the company performance and that high performance is needed to attract the best talent.

9. Sixty eight per cent of the companies have considered the education and experience of an individual very important factor in determining reasonable compensation for executives.

10. Hundred percent of the companies have considered other individual factors such as abilities, responsibility to be of extremely important in determining reasonable compensation for executives.

11. Fourth -fifth of the companies consider the industry in which the company falls when fixing the compensation package of executives. The implications given in regard to this is that the possibility of an attractive compensation package is with companies falling under the industry with good reputation.

12. Fixing compensation Package of executives with the Industry perspective, the companies response in a sequence of importance are; eighty percent of the companies consider the market condition extremely 
important in fixing up the executive compensation package. Secondly eighty percent consider the influence of economic conditions very important. Thirdly, a noticeable number that is sixty percent of the companies consider the availability of talent.

13. Hundred percent of the companies have established the compensation committees who determine the appropriate executive compensation package.

14. Three-fifth of the companies has reasoned that the compensation program is designed with the objective of encouraging executives to manage from the perspective of owner with equity stake in the company. The reason most companies practice the new emerging program Employee Stock Options Plan (ESOP).

15. Meager number of companies has compensations established with the objective of differentiating strongly so that their company best performers receive high competitive compensation package and poorer performer less.

16. Forty percent of the companies have experienced cases of executive resigning and leaving the country for greener pastures.

17. Most companies have given an explanation that India is among the third world countries with a rapid growing economy and thus most companies are convinced to foresee a bigger shift in compensation issue in the near future.

\subsection{Suggestions}

The conclusions of this study have revealed that a meager number of companies have experienced cases of executives resigning and leaving the country for greener pastures. However before one could proceed to make any suggestions to the company in India in view of the executive compensation. It is essential to understand that compensation in the Indian standards have been competitive and appropriate as a developing nation. On a comparative note, India as a whole is progressing extensively as there are many other country's which are yet to reach Indian standards. Therefore, slowly but without doubt India will experience a shift to global compensation standards.

The following suggestions are given to the companies in India to further modify its executive compensation package in order to realize the global compensation standard.

- Executive compensation need to be viewed as a total package composed of salaries, bonuses, long-term incentives performance based incentives, commission, benefits and perquisites.

- The current composition in most companies in India is composed of companies' officers. Therefore, there is a need to change the composition of the compensation committee and give it more independence. Some of the changes that company may include are:

- Prohibiting "inside" company officers and board members from serving on compensation committees.

- Also company may have to empower the compensation committee to hire and pay compensation consultants without involving executive management.

- With a strong emphasize put on performance rewards of executive, companies need at all time maintain and strictly scrutinize the two performance measure i.e., financial and non-financial organization measure used when determining the performance rewards of executive. The reason is to curb the known manipulation by executives, that temporary make organisational performance look better but in the long run may impair the growth of the company.

- Satisfaction level of companies with the existing executive compensation package leaves a lot to be researched on. The research could be to define the satisfaction level of companies in reference to the twofactor motivation theory of Frederick Hertzberg.

- Companies have strongly supported the fact that a good CEO or any executive can have a positive effect on the company performance and that high compensation is needed to attract the best talent. The suggestion to this is that companies need to be vigilant of the probable problems associated with exceeding executive compensation package such as resulting to be complacent with their work. On the contrary, this could highly impair the growth of the company.

- Companies need to judge all the factors on hand when identifying comparables for compensation benchmarking purposes. The basis to that omitting one factor could lead to offering unreasonable executive compensation package.

- The compensation program established in most of the companies, need to give a strong emphasize to differentiating strongly so that their company best performers receive high competitive compensation package 
and poorer performers less. This could egg on the Total Quality Management (TQM) in a company. In another words, payments for results philosophy need to be adopted.

\section{References}

\section{Publications}

Aswathappa K. (2005) Human Resources and Personnel Management, New Delhi: Tata McGraw- Hill Publishing Company. Dr O.R Krishnaswami (2003) Methodology of Research in Social Sciences: Himalaya publishing House; Bangalore Hartman L.P (2003) perspective in Business Ethics, Tata McGraw Hill Edition: New Delhi Michael V.P (2003) $5^{\text {th }}$ edition Research Methodology in Management: Himalaya publishing House Sarma A.M (2003) Personnel and Human Resources and Personnel Management. Mumbai: Himalaya Publishing House Noe.R.A( 2004 )Human Resource Management : Gaining a competitive advantage. Fifth edition, Tata McGraw Hill Companies.

Journals

HRM Review- Organisational Strategy and HR: July 2004; ICFAI University Press

Havard Business Review - What makes and Effective Executive; Article Understanding 'people' by Timothy Bulter and James waldroop Abhigyan- Quest for Excellence; April - June 2004; Article-" Human Capital: Its valuation and Management" by Lyndon Jones; ISSN 0970-2385, Volume XXIII, Number 1

\section{Websites}

http://www-rcf.use-edu- $\sim \mathrm{kj}$

http://www.dmr.com/compensation

http://www.en. wikipedia.org/wiki/minimum wage.

wwww.google .com the compensation game source: moneycontrol.com

http://www.compensation sources,. Com /services/executive-compensation php\# question

\section{Newspapers}

Business line Newspaper, Thursday, November 10, 2005

Financial daily from the Hindu group of Publications 